\title{
Gypsy Population of Tatarstan: Attitude to Education and Health
}

Tatyana Alekseevna Titova

Kazan Federal University

Elena Valeryevna Frolova

Kazan Federal University Corresponding Author

\section{Elena Gennadievna Gushchina}

Kazan Federal University

\section{Anastasia Victorovna Fakhrutdinova}

Kazan Federal University

Doi: 10.36941/jesr-2019-0022

\begin{abstract}
The studied problem significanceis caused by theneed of complex study of the groups which are in an nonnative environment environment. The purpose of the article is study of the of the Gipsy population that live in Zelenodolsk district of the Republic of Tatarstan to the systems and education healthcare. The leading approach to a research of this problem is a polyparadigmal methodology. The educational process is understood as an instrument of socialization of Roma children and health problems of representatives of their population. Special attention is paid to the circumstance that the questions of education of children is far from being priority one for the Gipsy population of the explored area. The understanding of health protection haw essential differences in comparison with local population. The conclusion is drawn that integration of Roma into local community depends on support of initiatives of locals and administration by most of representatives of a camp. Materials of the article can be useful to ethnologists, social and cultural anthropologists, political scientists and also representatives of the bodies/ committees and institutions supervising questions of interethnic and inter-religious interaction.
\end{abstract}

Keywords: gipsy population, health, education, interethnic interaction, integration, ethnocultural distance

\section{Introduction}

The Republic of Tatarstan historically is multinational and multi-religious region in the Russian Federation. During the present period the ethnic landscape of the Republic in many respects is defined by interaction of groups of the ethnic majority (Tatars and Russians) and ethnic minorities to which number belong Roma. The cultural distance between groups of the ethnic majority and Roma in the Republic of Tatarstan is shown in various behavioral and household practices, including, various relation to questions of education of children and health care. The discrepancy in cultural installations of Roma and local population increases the level of conflictogenity in society. In this regard, the study of behavior strategies of the Gipsy population of the Republic of Tatarstan in questions of education and healthcare is defined by requirements of multinational and multi- 
religious society of the Republic of Tatarstan. The specified strategy has an impact on intergroup interactions in labor, cultural, leisure spheres, the nature of interpersonal communication. It also influences interethnic and inter-religious relations in the Republic.

The interethnic relations in society are implemented at two levels: institutional and intergroup. The first is studied mainly by ethnopoliticalscientists, the second by ethnosociologists (Drobizheva, etc., 2016; Saidi, \& Siew, 2019; Baykalova, et al 2018).

Ethnosociology studies interethnic interaction through opinions, installations, orientations, values of people in different spheres of life - business, production, leisure, family.

Strategies of designing of ethnic identity define a wide range of problems for perspective research.

\section{Methods}

The research is based on the methodological principles of polyparadigmal approach. In the context of our research two provisions of the theory of $F$. Bart are understood as basic: first, a conclusion that the socially-set factors are cornerstone for the phenomenon of categorical attributing, but not "objectively" existing cultural distinctions are determinant for membership in group. Secondly, ethnic categories, both at the identification, and referencing of others to certain ethnic groups take into account not just the sum of objective distinctions, but only those that are perceived by individuals as significant (Barth, 1989; Fateminasab, 2014).

Article is based on materials of the field research conducted in the summer of 2016 in Zelenodolsk district of Tatarstan in places of compact accommodation of Roma. Procedure was conducted by number of interviews both with locals and with representatives of the Gipsy enclave. In this article materials of an interview with locals concerning questions of the attitude of Roma to the educational systems and healthcare are presented.

\section{Results And Discussion}

On the territory of settlements Aysha and NizhniyeVyazovyeof Zelenodolsk district is the biggest settlement if the Roma in Tatarstan today. They began to form in the early nineties when to NizhniyeVyazovye arrived the first groups of Gipsy and received from local authorities the earth for construction of housing. In 2000 the number of Gipsy population has increased up to 300 people, at the same time there was a split, and two big families have moved to the settlement Aysha basing there another (second) camp and new hierarchy with the new baron. "Here we live with Roma for almost 15 years. In Lower Vyazov there was a big settlement of Roma. 15 years ago 2 barons haven't found a common language, the camp was separated, and 2 families have arrived to Aysha. They have bought territories of 2-3 houses and settled there. Now it is 289 people." (from an interview with inhabitants of Aisha).

To define the exact number of the Gipsy population is rather difficult because only $30 \%$ of Roma have registration according to data of local administration. Under assumptions of locals, about 300 people live in each of the settlement camp. While the number of gypsies constantly grows, Roma don't hurry to legalize the accommodation: "Here from more than 300 Roma registration only 112 have registration. They can't even be counted! They have much arrived from Penza and in the passport one may observe a registration, not local. That is why they should to police noted that they have arrived, but they don't do this too" (from an interview with inhabitants of Aysha).

Critical moment in problem of Roma socialization is education. In the Gipsy environment value of education isn't supported and this is considerably reduces the prospects of positive interethnic interaction. More than a third of local Gipsyaren't able to read and write. In the settlement LowerVyazovy Gipsy children study in classes with local children. According to observations of teachers, children not always attend classes, don't perform completed homework, however don't essentially ignore school system and don't disturb other children, wear a school uniform, and their parents attend school meetings: "The class teacher communicates directly with parents. The school uniform is observed, it is not really expensive. Parents even pay for food in school canteen "; "They 
sit even if they don't do anything, but disturb nobody" (from an interview with teachers of school of the settlement Lower Vyazovye). In Aysha situation is more intense. For a long time the Gipsy children didn't attend school, and in 2011 the administration of local school has made the proposal on their exception. This proposal leaded to nothing as soon as it was a contradiction to the law, but has provoked the conflict with the Gipsy population: "We thought them to exclude, but it is impossible. The conflict has burnt out. We have contacted local administration. It appears, they can't bring children into school by 8 in the morning because they sleep up to 12." (from an interview with teachers of the school of Aysha).

Unwillingness of Roma to follow minimum requirements of educational institution by residents of the settlement Ayshais regarded as a refuse from any attempts of integration into local community. It is brightly traced in comments of respondents: "They consider that we earn money on their school attendance. There is no respect for anybody. Live as parasites. It is impossible to cultivate them. The school is not able to cope with this situation. May be to isolate these children, bring them up separately". (from an interview with inhabitants of Aysha).

For decrease in level of conflictogenity and solution of the problem of Roma children education the administration of Aysha settlement with assistance of Academy of Sciences of the Republic of Tatarstan has organized a separate Gipsy class with the special schedule, support in acquisition of a school uniform and school supplies has been also given. According to residents of the settlement all necessary measures have been taken by the local government for stimulation of Roma to enroll their children into education, but haven't received a due response of an innovation: "We have decided to make him the step schedule. But parents are not interested in it. We have created them extra comfortable conditions, they come when want, eat, then study" (from an interview with administration of the school of Aysha). Inoculation of school culture to the Gipsy children is complicated by the fact that parents in the majority don't support the educational initiatives: "They don't help children with homework; they have no idea of a schoolbag! They have in a package all materials that we give them, they at the end of the day the leave it at school. We give textbooks to children and we take them away at the end of the day" (from an interview with teachers of school of the item Aisha). Roma consider that the purpose of education is to develop at children such values as respect for seniors and care of family. School disciplines in this aspect seem to them useless: "The baron considers that they give the best education. The Russian children leave and don't respect their parents. Roma people don't give up parents, don't give up children, they do not have nursing homes for elders" (from an interview with teachers of school of Aisha).

It is also worth noting the fact that the Gipsy children, as a rule, attend only elementary school. According to features of marriage culture of Roma, boys marry in 10-12 years, girls at 11-13. Some girls are taken away to other regions for marry, those who get married in a camp are forced to keep houses in this connection there is no cease for them to attend school: "Children graduate from their elementary school and somewhere leave. They marry when they are 12 years old, taken away and that's it." (from an interview with inhabitants of Lower Vyazovye). Thanks to the educational initiatives in the area with assistance of local schools, educational level in the Gipsy environment increases, but extremely slowly.

The problem of health maintaining among representatives of the Gipsy enclave is very relevant. They are involved into healthcare system only partially, and mostly, continue to perform diagnostics and treatment of diseases by traditional methods. Requests for medical care they most often practice in a case of children diseases. As a rule Roma don't call the ambulance, and prefer to visit the doctor at home. The pediatrician of the settlement Lower Vyazovye has to make concessions: "When our pediatrician visits gypsy, they seldom let him in. They go to doctors houses, doctors don't refuse. If only came. They look after their children, but in a different way" (from an interview of inhabitants of Lower Vyazovye). Such behavior shows, in our opinion, the mistrust of Roma to a healthcare system and shows the transformed Gipsy custom of going to "witch doctor".

Childbirth at Gipsy takes place at home, or at difficult cases in hospitals. Women in labor allow to carry out completely all necessary postnatal procedures for the child, but themselves refuse from the medical care: "They give birth in maternity hospital or at home, but they leave maternity hospital 
next day. When I gave birth to the son, in parallel with me was a Gipsy woman, she even didn't not come into chamber, spent the night at a post on a mattress, and in the morning she took the child and left" (from an interview of inhabitants of Lower Vyazovye). On regular inspections Roma parents bring their newborns seldom, nevertheless show consideration for home care of their babies.

The ignorance of Roma in health issues repeatedly provokes conflict situations in the region . So, during vaccination of residents of the settlement Lower Vyazovye during the outbreak of hepatitis A, Roma refused inoculations. It has become clear that they aren't familiar with practice of vaccination. The similar situation has arisen also in Ayshasettlement :"They had no inoculations, before? They even don't know about them. When doctors started inoculations, there was the whole war" (from an interview with inhabitants of Aysha). Administration organized several open meetings with doctors who explained to Roma sense and advantage of vaccination in detail. According to the statements of respondents, there are no problems concerning inoculations today, Roma have realized importance of this procedure: "Meetings with doctors were organized, now with inoculations everything is normal, they have understood that it is good" (from an interview with inhabitants of Aysha). Somewhat the trust of Roma to the state policlinics grows, even more often they ask therapists for medical care: "Whether they address for medical services? - Recently even for consultations, seat in queues " (from an interview with inhabitants of Aysha). It is possible to claim that process of involvement of Roma in a health care system is started; however it requires constant stimulation and support from local authorities.

Residents of settlements consider that for the solution of the "Gipsy problem" is not only single actions, but also the comprehensive program of integration and adaptation, which would cover all spheres of life of Roma and require to be actively supported by the authorities. With such purpose at the initiative of administration and the Zelenodolsk representative office of Assembly of the people of Tatarstan in Ayshinsky rural settlement the Union of the Gipsy women has been created. The idea of the Union was discussed previously with the baron of a camp and has been approved by him. For several months for the Gipsy women meetings with pediatricians, psychologists, cooks were organized every week, discussions on health, personal hygiene, standards of behavior in society were led. According to residents of Aysha, such meetings have put the beginning for positive dialogue between local women and representatives of the Gipsy diaspora: "The administration has decided to create the Union of Gipsywomen; it was even wanted to be registered. We have decided to come every Wednesday to them. Have given classes on cookeries, class in psychology, have organized a meeting with doctors" (from an interview with inhabitants of Aisha). Today, the Union of Gipsy women works irregularly because hasn't received due financing support. The idea to extend action of the Union to a camp in Lower Vyazovye has also not been realized: "In order that somehow to organize them we cooperate with Assembly of the people of Tatarstan, we in Zelenodolsk have a representative office of Assembly of the people of Tatarstan, the chairman is - we cooperate with her. But they don't help in any way" (from an interview with inhabitants of Lower Vyazovye). Importance of similar initiatives in the course of integration and adaptation of Roma is indisputable, however the effective result requires their systematical realization on a constant basis.

Researches of processes of interethnic interaction in various regions of the Russian Federation are relevant for representatives of various scientific directions (Turukanova,2011). Sociologists study ethnosocial and ethnoconfessional aspects of intergroup interactions in modern society (Kuznetsova I.B. Mukhariamova L.M., VafinaG.K. ,2018; Drobizheva, 2009). Political scientists are interested in problems of influence of a condition of the interethnic and inter confessional relations on state policy and social processes in society (Titova, 2015; Abdulatipov, 2004). A specific sphere is held by study of psychological aspects of interethnic and inters confessional interaction. Researchers are interested in the size of an intergroup distance between the accepting population and foreign culture groups, the level of xenophobia, feature of social contacts between representatives of representatives of various religions and nationalities. In focus of the analysis there is, in particular, a study of a social intergroup distance and religious in polyetnichnycal and polyconfessional society (Titova, Sabirova, Frolova, 2016). At the same time, studying of features of intergroup installations in polietnichny regions of the Russian Federation 
demands deeper studying. In the real research the group of authors has studied the strategy of behavior in education and health of the Gipsy population of the Republic of Tatarstan.

\section{Summary}

Current situation has created rather complex relationship of Roma with local population. The initiative from local authorities of carrying out a complex of the organizational actions towards the integration of foreign culture group into local community is necessary for decreasing an ethnocultural distance between Roma and local population. However, the efficiency of such measures will be reached only with reciprocal support from representatives of the Gipsy camp of both settlements.

\section{Conclusions}

The materials presented in article can have the scientific and humanitarian and practical importance. Materials of article can be useful to experts in the field of social sciences: ethnologists, social and cultural anthropologists, political scientists and also representatives of the bodies and structures supervising questions of interethnic and interfaith interaction.

\section{Acknowledgements}

The work is performed according to the Russian Government Program of Competitive Growth of Kazan Federal University.

\section{References}

Abdulatipov R.G.(2004) Ethnopolitology, Spb:Piter.

Barth , F. (1989), Analysis of Culture in Complex Societies?, Ethnos, № 4, pp.120-142, 1989.

Drobizheva L.M.(2009) Russian Identity in Russia and Regions.-M.:Institute of Sociology RA of S.

Baykalova, E. D., Artyna, M. K., Dorzhu, N. S., Ochur, T. K., \& Mongush, D. S. (2018). Morphological interference in the process of mastering English speech in conditions of interaction of Tuvan, Russian and English as a foreign language. Opción, 34(85-2), 35-60

Drobizheva L.M. (2016)Positive International Relations and Intolerance Prevention, M.Spb.:Nestor-Istoria.

Kuznetsova I.B. Mukhariamova L.M., Vafina G.K. (2018)Migrants health as a social problem http://kazanmedjournal.ru/component/k2/item/686.

Fateminasab, A. (2014). Investigating the challenges and barriers of convergence between Iran and republic of Azerbaijan, UCT Journal of Social Sciences and Humanities Research, 2(1): 18-24.

Saidi, S. S., \& Siew, N. M. (2019). Assessing Students' Understanding of the Measures of Central Tendency and Attitude towards Statistics in Rural Secondary Schools. International Electronic Journal of Mathematics Education, 14(1), 73-86. https://doi.org/10.12973/iejme/3968

Titova , T. A. Sabirova, A.N., Frolova,E.V. (2016). "Collective social and cultural distance in the sphere of interethnic relations in the Republic of Tatarstan", The Turkish Online Journal of Design, Art and Communication, Vol. 6, November Special Edition, pp : 2817-2822.

Titova, T.(2016) "The host population and the migrants in modern Tatarstan: Social roles and intergroup distance", Journal of Organisational Culture, Communications and Conflict, Vol.20, Is.Special Issue 2, pp.166-172, 2016.

Titova, T.(2015) "Ethnic Cultural and Religious Practices of Migrant Women in the Republic of Tatarstan", Journal of Sustainable Development; vol. 8, No. 4; 2015. pp. 177-186, 2015.

Titova, T. (2016), "Ethnic identity and ethnocultural needs of the modern Russian rural population of Tatarstan (based on ethnosociological research) "Man in India, vol.97, Is.9, pp.1-7, 2016.

Turukanova , M. (2011)Women Migrants from CIS in Russia|/ Turukanova , M:Max Press. 